\title{
Recharting the History of Economic Thought: Approaches to and student experiences of the introduction of pluralist teaching in an undergraduate economics curriculum
}

\author{
Kevin Deane ${ }^{1}$ \\ Elisa Van Waeyenberge ${ }^{2}$ \\ Rachel Maxwell ${ }^{3}$ \\ ${ }^{1}$ Senior Lecturer in International Development \\ Department of Economics, International Relations and Development \\ University of Northampton \\ Park Campus \\ Boughton Green Road \\ Northampton NN2 7AL,UK \\ Kevin.Deane@northampton.ac.uk \\ ${ }^{2}$ Senior Lecturer in Economics \\ Department of Economics \\ SOAS \\ 10 Thornhaugh Street \\ Russell Square, London WC1H OXG \\ ew23@soas.ac.uk \\ ${ }^{3}$ Head of Learning and Teaching Development: Policy and Practice \\ Institute of Learning and Teaching in Higher Education (ILT) \\ University of Northampton, \\ Park Campus, \\ Boughton Green Road \\ Northampton, NN2 7AL, UK \\ Rachel.Maxwell@northampton.ac.uk
}

\begin{abstract}
This paper outlines an innovative redesign of a course on the History of Economic Thought, which acted as a vehicle for exposing students to different theoretical traditions and engaging them in critical reflections on neoclassical economics. It also presents findings from a research project conducted with economics students at the University of Northampton, UK, that aimed to understand their experiences of the redesign. We reflect on the pedagogical challenges highlighted by students and its implications for (re)designing the economics curriculum. Our findings challenge arguments commonly deployed against the introduction of pluralist teaching, including that there is no appetite for this in the broader student population; that students would fail to engage with such an approach; that they fear a negative impact on employability,
\end{abstract}


and that alternative economic approaches should only be introduced at an advanced level. ${ }^{1}$

Keywords: Heterodox economics, pluralism, flipped classroom, History of Economic Thought, pedagogy, curriculum reform, student experiences

\section{Author Bios}

Kevin Deane is a Senior Lecturer in International Development at the University of Northampton, UK. His educational background is in development economics, and he currently teaches international development and the history of economic thought. His research interests include the political economy and social determinants of health, with application to the HIV epidemic in sub-Saharan Africa, the economics of mental health, and qualitative research methods. He has published in journals from a range of disciplines, including development studies, global health, and political economy. Together with Elisa van Waeyenberge, he is in the process of finalising a textbook entitled Recharting the History of Economic Thought (Palgrave MacMillan, forthcoming).

Elisa van Waeyenberge is a Senior Lecturer in Development Economics at SOAS, University of London. She teaches macroeconomic analysis and research methods and is a departmental research tutor. Her research interests include alternative macroeconomic policies in developing countries, the role of International Financial Institutions across policy and scholarly realms, as well as the financing of infrastructure and public service provision. She has authored a number of articles on these topics as well as edited books with colleagues, including The Political Economy of Development: The World Bank, Neoliberalism and Development Research (together with Kate Bayliss and Ben Fine). Together with Kevin Deane, she is in the process of finalising a textbook entitled Recharting the History of Economic Thought (Palgrave MacMillan, forthcoming).

Rachel Maxwell is Head of Learning and Teaching Development at the University of Northampton. Her role includes leading institutional projects to develop policy and practice that drive the University towards its strategic goals. Current areas of focus include supporting student retention and progression, undertaking a generational review of institutional assessment and feedback and introducing a student-centred framework of graduate attributes. Rachel supports academic staff with an institution-wide shift in pedagogical practice to an Active Blended Learning $(A B L)$ methodology, helping to build capacity within academic Faculties. Rachel has a background in Learning Design and Learning Technology, including the planning and implementation of online and blended learning courses. Rachel is also a Fellow of the Higher Education Academy.

\section{Introduction}

\footnotetext{
${ }^{1}$ Jo Michel, Jeff Powell and Susan Newman provided comments on initial drafts of the anonymous survey. The University of Northampton funded the interview transcription and other related research costs. We are grateful to all the students who participated in this research. We presented early versions of this paper at the International Initiative for the Promotion of Political Economy Conference in Leeds, UK, September 2015, and also at the University of Dundee workshop on 'Teaching Economics in the 21 ${ }^{\text {st }}$ Century' in April 2016.
} 
Economists committed to pluralist economics teaching face a range of challenges in introducing alternative perspectives into the current curriculum, especially in departments where they are a minority and are unable to instigate comprehensive changes. These include, beyond the active resistance of neoclassical economists themselves: the limited space in most standard curricula in which the History of Economic Thought (HET) is often seen as 'a detour in comparison with a direct perusal of contemporary theory' (Roncaglia 2014, p. 1); concerns that the potential for future employment of undergraduates as economists would be harmed by this diversion of time; as well as institutional pressures related to enhancing student satisfaction. Further, calls for curriculum reform by student movements such as Rethinking Economics and the International Student Initiative for Pluralism in Economics (ISIPE) are often represented by those opposed to pluralist teaching as unrepresentative of the broader student population.

This paper outlines an innovative approach to introducing alternative economic perspectives into an economics curriculum through the redesign of a course on HET. In particular, the course was used as a vehicle for the introduction of pluralist teaching into an institution which did not have a history or tradition of doing so. It explicitly built on the 'competitive' view of HET, in which HET courses are used to 'confront students with the idea that there are different approaches to economics, and providing them with some notion of the conceptual foundations of such approaches' (Roncaglia 2014, p. 7). This is in contrast to the 'cumulative' view of HET in which contemporary (neoclassical) economic theory is viewed as the result of a gradual process of improvement and refinement in which 'the process of production of knowledge is taken to be perfect: whatever is good and valuable will be retained, whereas whatever is weak and erroneous will be weeded 
out' (Kurz 2006). This paper also reports the findings of a small mixed-methods research project that assessed the students' experience of the introduction of pluralist teaching and the interactive teaching approach that was part-and-parcel of the course redesign.

\section{Recharting the history of economic thought}

\subsection{Background}

In the autumn term of $2013 / 14$, Kevin started as an economics lecturer. His job included launching a course on the History of Economic Thought (HET). Initially pursuing a traditional approach through a chronological overview of significant economists across the $\mathrm{HET}$, he soon realised that he failed to elicit his students' interest. Consultation with co-authors, a teaching-and-learning advisor, and a colleague economics lecturer, provided ideas for a dramatic overhaul of the course.

The course redesign was reflexive of two core demands emerging from within the student movement. The first, a more general one, addresses the desire to increase students' participation in the delivery of a course, creating the space for innovative forms of pedagogy 'based on challenge and collaboration' (NUS, 2014). The second demand is specific to the economics discipline, where students have expressed dissatisfaction with a neoclassical economics curriculum, in particular in light of its limited capacity to account for the causes and consequences of the global financial and economic crisis. Beyond the student movement, the redesign also reflected our desire (and colleagues) to promote pluralist economics teaching. The result was a new HET course which exploits the principles both of in-depth engagement with specific economists and a comparative approach across various schools of thought organised thematically, rather than chronologically, and in contrast to a neoclassical analysis. At the same time, the newly 
designed course explored innovative teaching techniques, in particular those drawing on the concept of the 'flipped classroom' popularised by Eric Mazur in the early 1990s through his work on peer instruction.

The university where the HET redesign took place is not known for pluralism or heterodoxy in its economics teaching. Its economics curriculum is standard, with core modules of quantitative methods, microeconomics and macroeconomics following neoclassical syllabi. Its students also do not actively seek heterodox economic approaches. This gives particular significance to this study. Further, whilst the pursuit of a pluralist approach to economics teaching is not actively opposed from within the institution (which might be so in other more prominent and committed mainstream economics departments), the constraints on the current curriculum design, which reflect challenges in terms of bureaucratic processes and gathering broader intellectual support among colleagues, implied that the easiest way to introduce pluralist economics teaching was through establishing space within the current teaching framework. This was done through the redesign of a second year undergraduate HET course.

\subsection{Redesigning the course}

Initially, the HET course was taught in traditional, chronological fashion. It started with Adam Smith, followed by a series of economists (following books such as Roncaglia (2009) and Spiegel (2002)). However, it was clear from informal student feedback and the lecturer's own experience that this approach was failing to engage students. This led to a mid-course redesign.

The redesigned course is divided into two parts. The first part (covering 10 weeks) aims to give students an overview of key economists across the HET and introduces the 
notion that what is considered to be 'economics' has changed over time. The assessment for this part consists of a group academic poster and an individual 1,000-word essay. For the poster assignment, the class is split into groups of three, with each group allocated an economist (from a choice of Friedman, Hayek, Jevons, Keynes, Malthus, Marshall, Marx, Ricardo, Smith or Veblen). The groups are tasked with producing an A1 poster on their economist, which should include: an overview of the economist's main theoretical propositions; a relevant quote from their original work; and the relevance of his (yes, not her, as the canonical textbook HET is highly gendered) ideas.

The poster assignment gives students the opportunity to explore one economist in detail and to appreciate the potential relevance of ideas of 'dead men' for current economic issues. The posters are presented at an exhibition where they are assessed by the lecturer and other invited academic staff. ${ }^{2}$

The 1,000-word essay asks: 'What is economics? How has the definition and focus of economics changed over time?'. This creates the opportunity for students to reflect on different schools of thought and the disciplinary changes resulting from the marginalist revolution. The two assessments are designed to provide an introduction to key ideas and concepts across alternative economic theories, and serve as reference for the second part of the module.

As traditional lecturing to students on the various economists was not working in this course, a deliberate attempt to introduce more active, collaborative learning was implemented. Elements of the 'flipped classroom' were introduced, seeking to position learning as an 'active and constructive process' (Dewey, 1902, p. 9). Typically, a flipped pedagogical model reverses the lecture and homework elements of a course. In the case

\footnotetext{
${ }^{2}$ The posters were not assessed in $2013 / 14$ as it was too late to change the assessment structure.
} 
of the HET course, students are expected to engage in some pre-work to gain familiarity and understanding of core content before applying that understanding to a sense-making task designed to bring about deeper learning, thereby coming to the face-to-face session with a deeper foundational level of knowledge and understanding. Through this approach students are expected to 'engage [with] the task appropriately and meaningfully' (Biggs, 2003 , p. 16), building on a constructivist approach to learning that draws connections between theoretical concepts and practical application of knowledge and understanding to the real world (see Marton and Säljö, 1976; and Vygotsky, 1978).

Consequently, apart from an introductory and concluding lecture in weeks 1 and 10 respectively, there are no lectures during weeks 2 to 8 . The poster presentation assessment takes place in week 9 . Instead, during weeks 2 to 8 , the lecturer's contact hours are re-organised by giving each group fortnightly appointments during the timetabled teaching hours to discuss their research and progress towards the preparation of the poster and accompanying essay. The appointments take place at these intervals to give students time to engage in reading and reflection. It is made clear from the outset that the quality of the appointments depend on the self-study that students undertake.

The intention behind this approach is simple. In providing an opportunity for students to study one economist in depth, they are developing metacognitive skills in group work, research, synthesis and communication, thereby allowing allocated teaching time to be used to personalise learning and address areas of pre-identified need through a student-led model. While the flipped approach places a considerable onus on students to undertake independent study so as to be prepared for meetings with their tutor, the benefits of adopting this personalised needs-based approach can outweigh the disadvantages of a more traditional lecture format where the 'expert' takes time to 
ensure that everything is covered, 'just in case'. The approach also serves to move away from a focus on pedagogy towards a mix of andragogy (adult-learning) and a more selfdetermined, heutagogical ${ }^{3}$ approach.

This approach reflects active learning as 'engag[ing] students in the process of learning through activities and/or discussion in class, as opposed to passively listening to an expert' (Freeman et al. 2014, p. 8413-4). The opportunity for each group to meet for more tailored input from their tutor reflects the finding by Jensen et al. $(2015$, p. 8$)$ that possibly the most significant influence on student learning is time with the instructor (see Asef-Vaziri, 2015; Gilboy et al. 2014; Hung 2015; and Love et al. 2015).

The lecturer's experience of this process, however, was mixed. There were brief (and disappointing) meetings with unprepared groups where the lecturer had to resist reverting to traditional content delivery. There were also exceptional meetings with students who had prepared questions and drafts for discussion. This enabled the lecturer to assist reflection on their work. However, further research is necessary to explore whether more clearly defined expectations around preparation for face-to-face sessions in a flipped, active learning situation result in comparatively higher gains in student achievement.

Following the poster presentation exhibition and assessment, the concluding lecture in the first part of the course discusses the key differences between the classical and marginalist schools. This is done by exploring the economic problems they address as well as their approach to value, prices and income distribution (Roncaglia, 2009). This enables a brief overview of the historical development of different schools and some further commentary on method and analytical categories. The lecture also touches upon

\footnotetext{
${ }^{3}$ Heutagogy is defined as 'self-directed learning' as opposed to andragogy (adult learning) or pedagogy (children's learning).
} 
the formalist revolution (Blaug, 2003) and economics imperialism (Lazear, 2000), extending the narrative to the present day. This helps to situate the initial narrowing of the economics discipline, followed by its re-expansion through the application of its technical framework to a wide range of issues (Milonakis and Fine, 2009).

The second part of the course examines neoclassical economics critically and assesses the analytical strength of alternative economic theories. The first lecture introduces students to the debates concerning the relevance of neoclassical economics provoked by the financial crisis. This includes a discussion of the argument that neoclassical economics was to blame (Skidelsky, 2010) and the demands of the student movement for changes in economics teaching (The Post-Crash Economics Society, 2014). Subsequently, each lecture is organised around a specific economic question and proceeds by a threestepped approach: ${ }^{4}$

1. What does neoclassical economics say about this issue?

2. Criticism of the neoclassical approach on its own terms (internal critique).

3. What do other economists say about these issues and how does this compare to the neoclassical approach?

This innovative approach charts ideas from the history of economics by organising them thematically instead of chronologically and applies these ideas to everyday economic issues. The aim is also to engage students in a critical reflection on the economics taught in the rest of the curriculum. The lectures are delivered in an interactive lecture style, accompanied by seminars to discuss real-world applications. What follows is an example of how this teaching approach is operationalized.

\footnotetext{
${ }^{4}$ The full list of questions is available on request.
} 
The first issue revolves around the characterisation of 'economic man' as a rational optimising agent. Through critical engagement with the question 'Are we all rational optimising agents?' a range of concepts (such as bounded rationality, risk and uncertainty, animal spirits, the economy as a system) are introduced. The session commences with a brief review of the key assumptions underpinning standard consumer theory and the properties that define strict rationality (reflexivity, completeness, transitivity, continuity, non-satiation and convexity (Varian, 1992)). Additionally, other assumptions are explored, including: given preferences; individuals as isolated and independent agents; utility measured on an ordinal rather than cardinal scale; and agents as endowed with perfect information and the power to enact their decisions.

At this point, rather than engaging students straightaway into a critical discussion of these assumptions, they are invited to conduct a number of simple puzzles. Adapted from Kahneman (2003), these enable a reflection on standard neoclassical rationality assumptions together with an introduction to the field of behavioural economics. The latter is distinguished by its incorporation of insights from psychology into the modelling of human behaviour (see Santos, 2011 for a critique).

Pursuing the comparative principle that runs throughout the second half of the HET course, the lecture proceeds by examining further the notion of rational optimising agents via an engagement with three major contributors to economic thought. First, Keynes' observations regarding decision-making are discussed, drawing from his 1936 work on the difference between probabilistic 'risk' (to which probabilities can be attributed) and uncertainty (things we just don't know), and the crucial role of 'animal spirits' in economic decision-making. Second, the issue of self-interest and social optima as attached to Adam Smith is examined, drawing on Wilson and Dixon (2006) (amongst 
others). One element of Smith's notion of self-interest is: to be loved and liked by one's fellow man, which cannot be fostered if self-interest is pursued without consideration of others, highlighting a more complex form of self-interest. ${ }^{5}$ This enables exploring the meaning of self-interest, its distinction from greed; and allows for a discussion on whether the self-interest that appears in neoclassical economics is of a reduced nature, stripped of contextual and moral influence.

A final economist discussed in the lecture examining neoclassical rationality assumptions is Marx. As with Keynes, Marx is an economist who may not typically be considered in a lecture discussing issues bearing on behaviour. Yet important insights regarding behaviour emerge from his propositions. First, associated with the Althusserian ${ }^{6}$ perspective, that people are bearers of the system - our behaviours reflect the systemic context within which they take form. This leads to an identification of how the capitalist system works as a key influence over decisions. Second, revisiting the famous quote from the Eighteenth Brumaire of Louis Bonaparte, (Marx, 1852), the notion is explored that human behaviour (or perhaps more accurately human action) cannot be understood in isolation from its historical context, which conditions and constrains agency-decisions are not made in a vacuum. This introduces a critical perspective on the standard neoclassical assumptions regarding behaviour (rational optimisation) and through the contrast-and-compare principle allows for discussion of alternative theoretical traditions.

\footnotetext{
${ }^{5}$ This strand of Smith's thinking regarding self-interest originates from his Theory of Moral Sentiments (1759) that preceded the Wealth of Nations (1776), offering a more nuanced view of human action often overlooked. This stimulated debates such as Das Adam Smith problem which sought to assess whether Smith's conception of human action was consistent across his famous works.

${ }^{6}$ Althusser, a French philosopher working within the Marxian tradition, emphasises the role that economic structures play in shaping (determining) human behaviour. Often considered a 'Structural Marxist', his reading of Marx focuses on 'the development of social structures and the mode of production' (Joseph 2006, p. 71), and thus 'structures rather than agents' (ibid p. 71) dominate his analysis.
} 
The rest of the second part of the course applies this principle across a range of topics, where neoclassical propositions are scrutinised and assessed against alternative accounts. Such an approach allows reconstructing (across a set of topics) the main building blocks both of neoclassical economics as well as a selection of alternative theories across the HET. Within the current design of the course, the latter tend to be dominated by Keynes, Marx and the Classics, but the approach could easily be adjusted to reflect a lecturer's own preferences.

A drawback is how economic thought has evolved over time and of the relationship between particular theories and their socio-historical context is lost. However, aiming for a more meaningful discussion of competing theories, we believe that the approach represents an innovative way to introduce pluralist and heterodox teaching in economics. Further, whilst this is not the focus of this article, evidence also suggests that introducing students to a broad range of perspectives can have a positive impact on learning outcomes (Marcovitch 2016), providing an additional justification for this approach.

\section{Assessing the student experience of the new teaching approach}

Keen to assess the redesign of the HET course, the authors undertook a research project that sought to understand how students experienced both the deployment of a novel teaching approach and their exposure to a range of different (and often new) economic theories. This section sums up the findings of this investigation.

\subsection{Methods}


A mixed-methods approach was deployed, combining a short online survey with a series of semi-structured in-depth interviews. The latter were conducted with two cohorts of students who had taken the HET course (2013/14 and 2014/15). The anonymous online survey was designed to provide an initial overview of students' views on these [the teaching approach and introduction to pluralist economic teaching] issues, rather than whether or not the redesigned course was an improvement on the chronological method of teaching first employed. ${ }^{7}$ This focus accommodated the reality that the second cohort of students had not experienced the 'redesign' aspect of the module as contained in the new format. The survey comprised 15 questions ( 4 of which were text boxes asking for opinions, views, or explanations of responses). All students were invited to respond via the online learning environment, with the initial invitation followed by reminder e-mails. The response rate of the survey was $32 \%$, with an (anticipated) bias towards the most recent cohort. ${ }^{8}$ Alongside the survey, semi-structured interviews were conducted to explore themes raised in the survey. Students were invited by e-mail to participate in the interviews using a random sampling process. Eight students participated, comprised of five from the $14 / 15$ cohort and three from the $13 / 14$ cohort. All interviews were recorded for transcription purposes and were conducted in the absence of the lecturer. ${ }^{9}$

We are aware of the possibility of a degree of self-selection bias in the sample of students who participated in the research, as perhaps those students who engaged more with the course were more likely to respond. This may have influenced the findings.

\footnotetext{
${ }^{7}$ The survey is available upon request.

${ }^{8} 43 \%(12 / 28)$ of the $2014 / 15$ cohort responded as compared to $28 \%$ (12/43) of the $2013 / 14$ cohort.

${ }^{9}$ For ethical reasons, the lecturer was not involved in the sampling process and did not know which students had been invited. The interview transcripts were only shared once identifying markers had been redacted.
} 
However, our survey findings also confirm that the cohorts were not characterised by students actively seeking pluralist economics teaching and thus constitute an appropriate sample from which to draw more general conclusions regarding students' experiences of pluralist economics teaching. Further, as noted by Harvey (2011) in a study which investigated a similar issue, in both the survey and qualitative interviews, we are attempting to understand attitudes and experiences, rather than aptitude or learning outcomes (Harvey 2011).

3.2 Results

Table 1 summarises responses to key questions in the survey. The rest of the survey included text boxes in which students were asked to provide strengths and weaknesses of the course, as well as to expand on their answers to specific questions.

Table 1 - summary of answers to key questions.

Source: Author's research

\begin{tabular}{|c|c|c|c|c|c|c|}
\hline \multirow[t]{2}{*}{ Question } & \multicolumn{6}{|c|}{ Possible responses } \\
\hline & $\begin{array}{l}\text { Before } \\
\text { starting } \\
\text { University }\end{array}$ & $\begin{array}{l}\text { During } \\
\text { the first } \\
\text { year }\end{array}$ & $\begin{array}{l}\text { At the } \\
\text { start of } \\
\text { the } \\
\text { second } \\
\text { year }\end{array}$ & $\begin{array}{l}\text { During } \\
\text { the HET } \\
\text { module }\end{array}$ & $\begin{array}{l}\text { After the } \\
\text { HET } \\
\text { module } \\
\text { had } \\
\text { ended }\end{array}$ & $\begin{array}{l}\text { I am not } \\
\text { aware } \\
\text { of this }\end{array}$ \\
\hline \multirow{2}{*}{$\begin{array}{l}\text { When did you first } \\
\text { become aware that } \\
\text { your first year modules } \\
\text { focused mainly on the } \\
\text { neoclassical approach } \\
\text { to economics? }\end{array}$} & $17.5 \%$ & $13 \%$ & $17.5 \%$ & $52 \%$ & & \\
\hline & Yes & No & & & & \\
\hline $\begin{array}{l}\text { Would you like more } \\
\text { exposure to alternative } \\
\text { economic theories in }\end{array}$ & $\begin{array}{l}87 \% \\
(n=20)\end{array}$ & $\begin{array}{l}13 \% \\
(n=3)\end{array}$ & & & & \\
\hline
\end{tabular}




\begin{tabular}{|l|l|l|l|l|l|l|}
\hline $\begin{array}{l}\text { your economics } \\
\text { education? }\end{array}$ & & & & & & \\
\hline $\begin{array}{l}\text { Did this module help } \\
\text { you make sense of } \\
\text { your other economics } \\
\text { modules? }\end{array}$ & $\begin{array}{l}78 \% \\
(\mathrm{n}=18)\end{array}$ & $\begin{array}{l}22 \% \\
(\mathrm{n}=5)\end{array}$ & & & & \\
\hline & Positive & Negative & & & & \\
\hline $\begin{array}{l}\text { Do you think this } \\
\text { module has had a } \\
\text { positive or negative } \\
\text { impact on your } \\
\text { understanding of } \\
\text { economic realities? }\end{array}$ & $\begin{array}{l}100 \% \\
(\mathrm{n}=23)\end{array}$ & & & & & \\
\hline
\end{tabular}

These survey responses were combined with an analysis of the data from in-depth interviewing. This gave rise to the identification of a number of themes regarding the students' learning experience of the new HET course. In what follows, we first present the main benefits and positive comments that students reported relating to their experience being introduced to a range of alternative perspectives. We then discuss a number of challenges highlighted by students which help to illuminate future improvements and considerations for those designing pluralist courses within curricula dominated by neoclassical courses. Finally, we present student views on the interactive, student-led element of the teaching approach.

\subsection{Engagement and Empowerment}

First, the HET played a crucial role in allowing students to situate neoclassical economics amongst a spectrum of schools. From the survey it transpired that 70 percent of respondents were not aware that they were mainly taught neoclassical economics in their curriculum until the start of the HET course. Throughout the interviews, this was a 
recurring theme, with many students surprised that they had previously been studying only one (particular) version of economics: 'Overall, I think that it was a really positive thing that [Kevin] introduced that and made my head explode, I guess, but it was really positive as now I have a broader view of economics as a whole' (Student 04, our emphasis). And for another student: 'It was interesting ... when you see all the other methods it was kind of like an eye-opening experience... because it's like you're being cheated, you're only being taught one thing when there's so much more' (Student 08, our emphasis).

While from interviews, it was gathered that awareness that neoclassical economics was not the only way to do economics caused some initial confusion (see below); this confusion generally gave way to interest, curiosity, and a sense of empowerment. Students felt they were acquiring tools to engage with economic realities that did not necessitate mastering complex mathematical skills. One student commented:

I've never done economics before. So my first year economics was all horrifically complicated maths to the point of it just looked like I was speaking Greek. Then suddenly I turn up and in my second year it's like no, economics is a load of theories as well, which was fine ... I suddenly thought ... I can do this economics stuff because it makes sense and it isn't a load of numbers (Student 07, our emphasis).

Once students realised that economics was not limited to maths but also included theorising, and that a space existed for them to participate in debate without feeling disenfranchised by the technical requirements of neoclassical economics, they gained academic confidence: 'it [HET] did give me at least the confidence to say you can actually argue rather than, no, it's [neoclassical economics] literal[ly] gospel' (Student 07).

All survey respondents reported that the course had a positive impact on their understanding of economic realities and that it broadened their horizons. It also enabled 
them to reflect on the subject matter of economics (and different definitions of

economics) as well as to relate economics to the world around them:

Because with economics, we're just taught neoclassical economics. So the fact that we've got to learn the other ways helped ... It makes it easier to explain to other people ... what we do in economics, when you can help solve a real world issue (Student 06, our emphasis).

The organisation of the HET course around a critical appraisal of neoclassical economics amongst a spectrum of competing economic theories allowed for 'sense-giving' or ordering of different economic propositions:

'That [the contrast-and compare approach] made more sense because it wasn't just more of looking at one person and all of their ideas, it made more sense of relating one theory and then looking at different economists within that theory, it made a lot more sense' (Student 03, our emphasis).

The redesigned HET course provided a perspective on the discipline where the absolute sense of truth often attached to neoclassical economics quickly dissipated:

For me it was a bit of a revelation because I thought, hang on, the economics I've been taught for the last year and a half turns out to not be the economics - it's not science, it's more sort of an argument rather than a direct [exact] science, which was new to me because I've never done the subject before (Student 07, our emphasis).

This was also apparent in relation to students' reflection on the role of assumptions, which previously were simply to be 'learned', but now became subject of debate and discussion: 'At first it was hard to understand, but after a while it became easy. Like everything that was presented to your assumptions, for example, you're able to criticise it and say whether the assumptions are actually correct' (Student 04, our emphasis).

These findings provide evidence of student interest for the introduction of alternative economic theories, even when students have not deliberately signed up for 
such an approach, as is the case for the institution where the new HET course was introduced. They also illustrate that once exposed to alternative theories, students respond eagerly. Our findings echo Harvey (2011), who also reported a positive reception of the introduction of an explicitly pluralist course. This evidence counters the commonly advanced arguments that there is no student appetite for the introduction of alternative theories and the implication that students in general are not happier when supplied with heterodox teaching (Yates 2014), and thus highlights the benefits of doing so in a comparative manner.

\subsection{Reforms - more (and earlier) please!}

Secondly, a majority of students indicated a desire for more exposure to alternative theories, an important finding given the background of the cohorts (see above). Further, across the different interviews it transpired that the economics education received during pre-university education is strongly biased towards neoclassical teaching, ingraining from the first encounter a narrow sense of the discipline's boundaries.

Some of interviewees had three years exposure to neoclassical economics before embarking on the HET course, worsening their confusion and sometimes shock. They had received little to no guidance in their earlier economics education on how different theories coexist. Throughout the interviews, students indicated that they should be exposed to alternative theories early in their education, and wondered why this had not happened: 'So I've been taught this for three years, but there's this as well. Why haven't we been taught this?' (Student 01). And again: 
However, at the same time, it would have been beneficial to me if I was introduced to it at a young age because I feel as if the more you're exposed to it, the more you understand instead of me having the single mind that this is the correct way of economics (Student 04).

This provides important insights for curriculum reform and casts doubts on the oft-heard argument that pluralist economics courses should be taught at a more advanced level. While we are not proposing that neoclassical economics should not be taught, a pedagogical approach that takes the broad spectrum of competing propositions as its point of departure from the beginning of formal economics education, including through pre-undergraduate education, would create a more balanced approach to the study of economics and would avoid the confusion when new theories are introduced at a later stage of study. As Roncaglia (2014) notes pertaining to concerns of complexity that pluralist teaching may introduce,

"This [authoritarian] attitude implies that eighteen-year-olds may have the right to vote in political elections but they still remain so simple-minded as to get confused when confronted with a simple fact of life, namely that there are different and often conflicting viewpoints for all aspects of life, including how a market economy works".

Further, teaching that involves looking at competing perspectives is hardly without precedence, with subjects such as sociology already teaching pluralism lines in preundergraduate (secondary) curricula.

3.6 Challenging and confusing

Thirdly, whilst the students reported a number of positive elements towards the course, they also noted that due to their lack of initial awareness of competing economic 
approaches and their sudden confrontation with a broader spectrum of the discipline,

they were often confused:

The problem is ... Since the start of A Levels I only knew neoclassical economics, and the thing is, I've been doing that for three years, and after three years, then now being exposed to this, it's hard ... this is going to criticise everything you've learned for the past three years, and trying to get your head around it, that was difficult (Student 01, our emphasis).

And again:

As the course started I was confused ... I've been taught ... neoclassical since year 11. I've been learning about supply and demand, so it was quite hard for me to understand the concept that there are theories based on other theories that have been developed over time. And so I was always confused. It took me a while to understand what Kevin's module was about literally. So, I struggled during the first couple of months (Student 04, our emphasis).

One unintended consequence, in contrast to some of the findings reported in Harvey

(2011), was that sometimes the perspective gained through the HET course also

produced distrust or disengagement with the students' standard micro/macro courses.

This is highlighted in the following exchange between student and interviewer:

Student 06: 'It made you more disengaged'.

Interviewer: 'From the other modules?'

Student 06: 'Because to an extent with certain topics they were potentially wrong because of the other stuff, because you're taught classical and Marxist and Keynesian ways of doing things. When you go back to your micro lecture and your lecturer it's like let's assume there's two people or two firms in the economy and you've just done history where you know that's not true. You can't say that for a real world issue'.

These findings present pedagogical challenges in relation to introducing alternative economic theories into existing mainstream curricula, the treatment of their relationship to the existing body of neoclassical thought, the timing of when alternative theories are 
introduced, and the challenges that the lack of earlier exposure to a broader spectrum of economic theories entails for both lecturer and students.

\subsection{Integration with other courses}

Fourth, the course raised important issues regarding how it comports with the rest of the curriculum. Students commented that the course remained isolated from other courses and indicated their uncertainty regarding how to use the knowledge gained through the HET across other courses

The perception was that the approach in other courses was rigid or 'set in stone' (Student 01) with few opportunities for critical engagement. For one student:

It was very isolated because that's the only time we're taught it so we can't really use it elsewhere ... but it kind of did isolate because you kind of have to forget when you did micro or macro because you're not marked on what Marx or what Keynes say (Student 08).

Another student wondered: 'For us, that was economics. And then when we suddenly discovered there was another bit, as I said, we looked back on what we'd done with all the maths and thought, hang on, where does that all fit into?' (Student 07).

Often, students expressed a fear of upsetting the lecturers in their other courses by raising what they saw as fundamental questions bearing on the relevance of what was being taught. Here a student points to the perceived limited knowledge of teachers in other courses, curtailing the possible use of knowledge gained through the HET across the rest of the courses: 'the other modules do not cross over enough to validate using what I learnt in this module as other teachers will not think points are valid due to them not learning anything else but neoclassical' (survey responses, p. 16). These concerns 
gave way to the expression by some interviewees of a desire to see a more integrated approach to teaching economic theory, where in standard micro/macro courses clearer sign-posting should happen regarding what particular paradigm or school of thought the theories are attached to:

The HET is on its own and it's basically telling you why each of your other modules are teaching you wrong things. And there's other views to things. But if it was blended in, I think it would be a lot better (Student 06).

Related, a desire was also expressed for better signposting in the other neoclassical economic courses:

It would have been nice if when we were doing macro saying on the macro course, 'We teach you this, this is a neoclassical perspective on it, but if you looked at it from this perspective then it would be different, there would be different models that you would follow'. That would be nice if they put in other models rather than being 'Okay this is the model, this is the way it goes' (Student 03).

Students also repeatedly expressed a desire for clarification on how different propositions relate to one another. Yet, the isolated nature of the learning experience in HET often created a sense of frustration for the students. One student sighed: 'what's the point of having knowledge if you can't use it' (Student 04).

Whilst there are challenges to integrating the HET course with other standard courses, students appreciated attempts by lecturers to do this. One example was a lecture on the role of maths in economics that was given jointly by the microeconomics and HET lecturers. This enabled different arguments to be put forward and provided an opportunity for students to draw links between different economic approaches. The joint lecture was carefully planned by both lecturers with agreed terms of engagement to 
ensure that the joint lecture would serve a pedagogical purpose, rather than becoming a contest or confrontation. A student positively recalls:

I think there was one bit we looked at where the maths was important ... I thought it was good the way that lecture was done, where it was two different lecturers, because not every lecturer is going to agree (Student 03).

A second example was the willingness of the microeconomics lecturer to set an assignment that provided scope for students to bring in a critical perspective on microeconomics. ${ }^{10}$ These examples illustrate that the integration of courses in lieu of a complete curriculum overhaul is possible but depends on the ability and willingness of other lecturers.

The unease regarding how the HET course comports with other standard courses, and that students find being introduced to alternative perspectives demanding and challenging, highlights the need for a comprehensive reconsideration of the economics curriculum; but at the same time, should not be exploited as reasons not to take action in the limited realm we often operate in. These insights are also useful for academics aiming to introduce pluralist courses, as well as for improving existing courses.Employability

Fifth, some students raised concerns that, whilst this was an interesting course, the knowledge of economists such as Marx (and others) would not enhance their employability skills. This is an argument frequently proposed by those seeking to prevent the expansion of pluralist teaching. One interviewee put this as follows:

I think it is useful, but ... if I go to a graduate employer and say, well, I know about Karl Marx, I know about the Austrian School, they're just going to turn round and

\footnotetext{
${ }^{10}$ The essay question invited students to engage in a discussion of the economics of happiness.
} 
be like ... well, we're Solow model. I'm pretty sure that they'll only look at the neoclassical, just because the fact is that over the years economics has been taught just neoclassical (Student 01).

However, some students were aware that their critical thinking had been sharpened as a result of the HET course. A student singled out the development of these skills as beneficial for future employability:

Purely on an employment level later on, it gives you an actual view of how you could actually use this in running a business in some way. You could see the different ideas and how to expand things ... I know it's not a business module, but you can see, it can hint at ideas so as a student you can actually see yourself actually using some of it ... (Student 07).

This debunks a common argument that is often deployed against the introduction of alternative approaches that students need to focus on core micro and macro theory as these offer a skill set that prospective employers are looking for. In such an argument, the study of the HET becomes a diversion from these core tasks. Our research illustrates that students are aware that the development of critical thinking skills is important for future employment prospects and that these skills are fostered through both the teaching approach and theoretical content of this course.

\subsection{Teaching approach}

Another component of the research project sought an evaluation of the pedagogical approach adopted in the revised module. Students who completed the survey indicated that the introduction of different teaching methods and the poster presentation were an engaging feature of the module. One student commented that the poster was 'definitely a good change because ... we were learning ... ourselves rather than 
just being talked at, so that was better' (Student 03). There was also recognition of the extent of self-learning that occurred through the assignment:

I remember me and a few of my friends that were doing it, we were like, 'We've learnt a lot just from writing the assignment'. Even though the module itself we didn't necessarily enjoy because it was difficult to understand everything, when it came to writing it, it made a lot more sense when you did the assignments. It was ... interesting self-learning (Student 03).

Another positive reflection was that the move away from a traditional lecture format indicated a degree of trust in students. For a student 'it was a lot of fun to research' (Student 06). Placing the onus on the student to engage more deeply was both noted and appreciated: 'if you wanted to have a good poster you would do a lot more research and read into trying to incorporate as much as you could... I think it was a good way of learning because ... you had to use your initiative' (Student 08). However, the same student also recognised that other students found this approach unsettling:

[I]n first year people might understand more that it's not all about the lecturer teaching you; it's about you learning yourself. I think people struggle with that because ... people are like, oh my god there's no lecturer, what am I going to do? They kind of thought it was a bad thing that they would have to learn themselves, whereas that's the whole point. ... But I think when people saw there was no lecture they took it as a free period (Student 08).

There were, however, concerns around the trade-off implied by the focused study of one economist as opposed to gaining a broader understanding of the history of economic thought: 'I guess there's no way of everyone doing every poster but it just made it more difficult because you were only learning one economist' (Student 03). This issue can be addressed in different ways. First, the poster assignment (with essay) can be expanded to require the submission of an annotated poster that requires all group members to 
expand upon their contributions to the poster. Second, an additional activity can be introduced requiring specific engagement with the poster presentations of other economists through reflection on their contributions to the HET and how a student's own knowledge has improved. This would also bridge the two parts of the course and address concerns raised by students that the poster exhibition only gave them in-depth knowledge of one economist.

\section{Conclusion}

This paper reported on an attempt to bring pluralism into undergraduate economics education in the context of a student population that had not explicitly signalled a desire for such a change. This was done through the use of an HET course. The redesign had a dual purpose: the introduction of a novel pedagogical approach through the promotion of student-led learning, and exploration of a spectrum of alternative economic theories in a compare-and-contrast manner.

Our research points to a broad degree of success with this approach. Students reported that the introduction of pluralist teaching was beneficial in helping them understand real-world economics, as well as neoclassical economics from other courses. The majority of them reported a desire for more pluralist teaching. Whilst students who participated in the research indicated initial confusion when confronted with a broader spectrum of economic theories, they were keen to acquire better understanding of various economic debates. The shift towards student-led learning also bore fruit via its contribution to the development of a new skill set, perhaps improving prospects for employability. 
However, students also reported some challenges and pedagogical issues with the sudden introduction of a broad range of economic approaches, especially that they previously had studied one version of economics. The led to some confusion, frustration and demotivation on the part of students, and also a concern about how the pluralist HET course was integrated with other neoclassical courses. These important insights can inform future pluralist course and curricula development to ensure that the introduction of pluralist teaching is better integrated and does not prove so overwhelming as to confuse and demotivate (though there is of course no harm in students being challenged intellectually). Further, the success of a student-led learning approach depended on the lecturer's willingness to guide the aims and methods to be deployed through self-studyan important component of this teaching approach, particularly at this institution (Salmon 2013).

The research has enabled us to challenge a number of myths regarding the desire, feasibility, and employability concerns typically used as arguments against the introduction of alternative perspectives in economics education. Students reacted positively to the lecturer's efforts to broaden their economics education; often expressing a desire for more such efforts, and to be introduced at earlier stages of the curriculum. For one enthusiastic survey respondent the course 'should be the start of a radical change in the higher education sector'!

\section{References}

Asef-Vaziri, A. (2015) 'The Flipped Classroom of Operations: A Not-For-Cost-Reduction Platform', Decision Sciences Journal of Innovative Education, Vol.13, No.1, pp.7189

Biggs, J. (2003) Teaching for quality learning at University, 2nd ed., The Society for Research into Higher Education \& Open University Press, London 
Biggs, J. and Tang, C. (2011) Teaching for Quality Learning at University, 4th Edition, Open University Press, Berkshire

Blaug, M. (2003) 'The Formalist Revolution of the 1950s', Journal of the History of Economic Thought, Vol. 25, No. 2, pp. 145-157.

Chang, H.-J. (2014) Economics: The User's Guide, Pelican, London.

Dewey, J. (1902) The Child and the Curriculum, University of Chicago Press, Chicago

Freeman, S., Eddy, S., McDonough, M., Smith, M., Okoroafor, N., Jordt, H. and

Wenderoth, M. (2014) 'Active learning increases student performance in science, engineering and mathematics', PNAS, Vol.111, No.23, pp. 8410-8415

Gilboy, M., Heinerichs, S. and Pazzaglia, G. (2015) 'Enhancing Student Engagement Using the Flipped Classroom', Journal of Nutrition Education and Behavior, Vol. 47, No.1, pp. 109-114

Harvey, J.T (2011) 'Student attitudes toward economic pluralism: survey-based evidence', Int. J. Pluralism and Economics Education, Vol. 2, No. 3, pp.270-290.

Hung, H-T. (2015) 'Flipping the classroom for English language learners to foster active learning', Computer Assisted Language Learning, Vol. 28, No.1, pp. 81-96.

Jensen, J., Kummer, T., and Godoy, P. (2015) 'Improvements from a Flipped Classroom May Simply Be the Fruits of Active Learning', CBE - Life Sciences Education, Vol.14, No.1, pp. 1-12.

Joseph, J (2006) Marxism and Social Theory, Palgrave, Basingstoke

Kahneman, D (2003) 'Maps of Bounded Rationality: Psychology for Behavioral Economics', The American Economic Review, Vol.93, No.5, pp.1449-1475

Keynes, J.M. (1936), The General Theory of Employment, Interest and Money,: Cambridge University Press for the Royal Economic Society, Macmillan, Paperback edition 1993

Kurz, H.D (2006) 'Whither the history of economic thought? Going nowhere rather slowly'? , The

European Journal of the History of Economic Thought, Vol.13, No.4, 463-488.

Lazear, E. (2000) 'Economics Imperialism', Quarterly Journal of Economics, Vol. 115, No.1, pp. 99-146

Love, B., Hodge, A., Grandgenett, N. and Swift, A. (2014) 'Student learning and perceptions in a flipped linear algebra course', International Journal of Mathematical Education in Science and Technology, Vol.45, No.3, pp.317-324.

Markovitch, I (2016) 'Does pluralism matter? Examining students' experiences of undergraduate economics curriculum in relation to the mission of the university', Int. J. Pluralism and Economics Education, Vol. 7, No. 4, pp.394-412.

Marton, F., and Säljö, R. (1976) 'On qualitative differences in learning: 1 - Outcome and Process', British Journal of Educational Psychology, Vol. 46, No. 1, pp.4-11.

Marx, K. (1852), 'The Eighteenth Brumaire of Louis Bonaparte', available at: https://www.marxists.org/archive/marx/works/1852/18th-brumaire/ (accessed 22/07/2015)

Mazur, E (1997), 'Getting Students to Think in Class', Harvard University [online]. Available at: http://mazur.harvard.edu/sentFiles/Mazur_274537.pdf (Accessed: $17 / 07 / 2015)$

Milonakis, D. and B. Fine (2009), From political economy to economics: method, the social and the historical in the evolution of economic theory, Routledge, Abingdon. 
NUS (2014), 'Radical Interventions in Teaching and Learning. How the partnership agenda can help create radical and inclusive learning spaces', available at http://s3-euwest1.amazonaws.com/nusdigital/document/documents/14853/7b346601c9e46 d97d53ce13e1d39e59d/NUS\%20Radical\%20TL.pdf?AWSAccessKeyld=AKIAJKEA56 ZWKFU6MHNQ\&Expires=1437132676\&Signature=QvpfzBMszspQC0DYgFYYPBF21J Y\%3D (accessed 15/07/2015)

Roncaglia, A. (2009), The Wealth of Ideas, Cambridge University Press, Cambridge.

Roncaglia, A (2014), ' Should the history of economic thought be included in undergraduate curricula?', Economic Thought, Vol.3, No.1.

Salmon, G. (2013) E-tivities: The key to active online learning, ( $2^{\text {nd }}$ edition.), Routledge, London and New York

Santos, A. C. (2011) 'Behavioural and experimental economics: are they really transforming economics?', Cambridge Journal of Economics, Vol.35, No. 4, pp. 705-728

Skidelsky, R. (2010), Keynes: The Return of the Master, Penguin, London.

Spiegel, H. (2002), The Growth of Economic Thought, Duke University Press, Durham.

The Post-Crash Economics Society (2014), 'Economics, Education and Unlearning: Economics Education at the University of Manchester', The Post-Crash Economics Society, Manchester:

Wilson, D and W. Dixon (2006) 'Das Adam Smith Problem: A Critical Realist Perspective', Journal of Critical Realism, Vol. 5, No. 2, pp. 251-272.

Varian, H. (1992) Microeconomic Analysis, New York, W. W. Norton \& Company Vygotsky, L. S (1978) Mind in Society,, Harvard University Press, Cambridge, MA

Yates, T (2013), Aditya Chakrabortty's one sided Radio 4 polemic on economics, https://longandvariable.wordpress.com/2014/12/03/aditya-chakraborttys-onesided-radio-4-polemic-on-economics/ , accessed 29 ${ }^{\text {th }}$ September 2017 